\title{
A COMPARISON OF THE TRANSPORT OF SPERMATOZOA IN SPAYED AND ENTIRE EWES
}

\author{
A. J. ALLISON* \\ Department of Animal Husbandry, The University of Sydney, \\ Sydney, N.S.W. 2006, Australia
}

(Received 1st December 1971, accepted 18th January 1972)

\begin{abstract}
Summary. The pattern of transport of spermatozoa in spayed ewes treated with $10 \mathrm{mg}$ progesterone for 12 days followed by $24 \mu \mathrm{g}$ ODB was compared with that in entire animals at two times of recovery following artificial insemination or natural mating. Spayed ewes had fewer spermatozoa in all sections of the tract than did entire ewes for all treatment combinations. The numbers recovered from the cervix and vagina were higher at 2 than at $24 \mathrm{hr}$ after insemination, while the converse was true for the Fallopian tubes. More spermatozoa were recovered from the Fallopian tubes of naturally mated than of artificially inseminated ewes but the difference was not evident in other regions of the tract. Histological examination of the uterine endometrium indicated an early stage of atrophy in the spayed ewes. Thus, hormonal regimens which will induce behavioural oestrus of 'normal' dimensions in spayed ewes will not maintain the functional integrity of the uterus and the transport of spermatozoa within the tract is grossly impaired.
\end{abstract}

\section{INTRODUCTION}

Oestrogen is necessary for the establishment and maintenance of a population of spermatozoa within the cervix of the ewe (Allison \& Robinson, 1972) and a balance of ovarian steroids appears also to be involved. The numbers of spermatozoa recovered from the cervix, uterus and Fallopian tubes of progesterone-oestrogen-treated spayed ewes were many fewer than those reported in entire ewes. In the only other published report on the transport of spermatozoa in spayed ewes (Mattner \& Braden, 1963), the numbers recovered compared favourably with those obtained from entire ewes under similar circumstances (Mattner, 1963). However, spermatozoa were recovered $3 \frac{1}{2}$ to $4 \mathrm{hr}$ after natural or forced mating whereas the data reported by Allison \& Robinson (1972) concerned recovery $24 \mathrm{hr}$ after artificial insemination. In this study, therefore, the transport of spermatozoa in spayed and entire ewes was compared following natural mating or artificial insemination.

* Present address: Invermay Agricultural Research Centre, Private Bag, Mosgiel, New Zealand. 


\section{MATERIALS AND METHODS}

\section{Experimental design}

Twenty medium wool Merino ewes were ovariectomized 7 weeks before the start of the experiment. Twenty similar entire ewes were used as controls. One spayed ewe died during the course of the experiment.

The ewes were randomized into a factorial experimental design along the following lines:

Type of ewe

Time of recovery (hours)

Type of mating

Spayed versus entire

2 versus 24

Artificial insemination versus natural mating

Factorial: $2 \times 2 \times 2 ; \mathrm{n}=5 ; \mathrm{N}=40$.

\section{Hormone administration}

Spayed ewes were subjected to two 'artificial' oestrous cycles (Allison \& Robinson, 1972) and the experimental oestrus was induced by similar treatment, namely $10 \mathrm{mg}$ progesterone/day for 12 days, followed $48 \mathrm{hr}$ later by a single injection of $25 \mu \mathrm{g}$ oestradiol benzoate (ODB).

For experimental convenience, the cycles of the entire ewes were synchronized with 12 daily injections of $10 \mathrm{mg}$ progesterone followed by 500 i.u. PMSG given at the time of the last injection. The ewes were used at the next cycle following this treatment.

\section{Insemination and mating}

Oestrus was detected by harnessed vasectomized rams. Semen for artificial insemination was collected by artificial vagina and ejaculates were pooled following a visual assessment of sperm density and motility, using only semen of high quality. Insemination was carried out with $0.15 \mathrm{ml}$ undiluted semen estimated to contain not less than $300 \times 10^{6}$ spermatozoa. Natural mating was by hand service to each of two rams within $5 \mathrm{~min}$. Entire ewes were inseminated or mated on detection of oestrus and spayed ewes $24 \mathrm{hr}$ after the injection of oestrogen. They were run in a small pen until just before slaughter.

\section{Slaughter of ewes and recovery of spermatozoa}

Ewes were killed at the laboratory by intracardiac injection of $3 \mathrm{ml} 60 \%$ sodium pentobarbitone solution. The reproductive tract was immediately removed and flushed. In general, procedures of flushing, storage and counting were as described by Allison \& Robinson (1972) except that the cervices were dissected away from the rest of the tract, immediately frozen in liquid nitrogen vapour at $-193^{\circ} \mathrm{C}$ and subsequently stored at $-20^{\circ} \mathrm{C}$. Immediately before counting, each cervix was divided into caudal, mid and cranial sections. Each section was dissected into six to eight longitudinal strips which were placed into a vial containing $10 \mathrm{ml}$ saline. The strips were left to thaw for approximately $30 \mathrm{~min}$ and then vigorously shaken before withdrawal of an aliquot for counting. Methods of counting were as described previously except that, for ease of counting, uterine washings were concentrated by centrifugation at $3500 \mathrm{rev} /$ $\min$ for $10 \mathrm{~min}$. 
Sperm transport in spayed and entire ewes

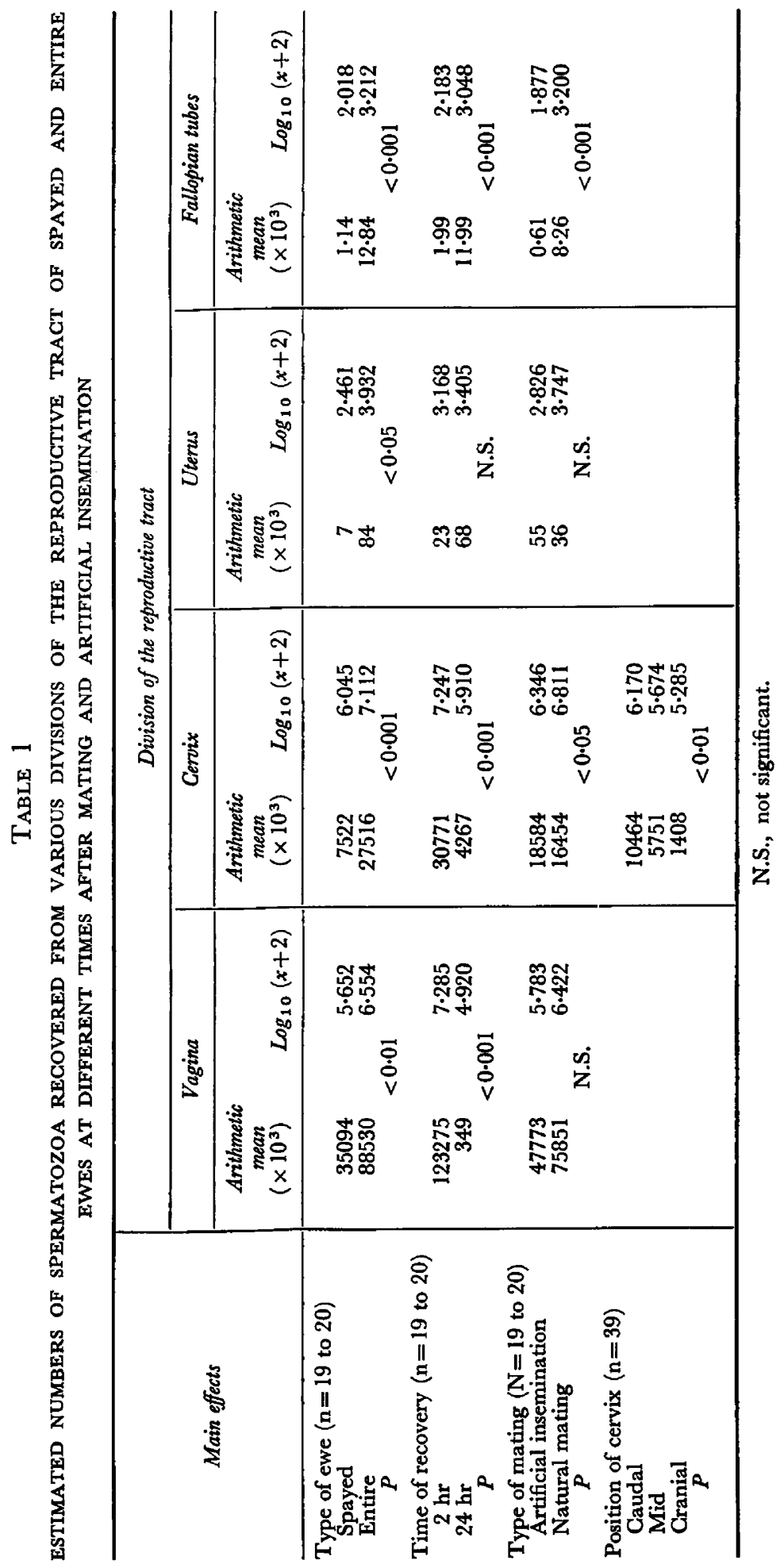


Analysis of the data for cervical counts was by a split plot technique (Cochran \& Cox, 1957).

\section{Uterine histology}

After flushing, a sample of the uterus was taken from one uterine horn midway between the external bifurcation and the uterotubal junction and placed in $12.5 \%$ formalin. Subsequently, each sample was dehydrated, embedded in paraffin wax and cross-sections were cut at $6 \mu \mathrm{m}$. Duplicate cross-sections were stained with haematoxylin and eosin or periodic acid-Schiff's reagent (PAS), and examined under a light microscope. The data recorded were: (i) height of luminal epithelial cells (intercotyledonary area); (ii) height of glandular epithelial cells (mid-gland region); (iii) width of myometrium; (iv) width of longitudinal muscle; and ( $v$ ) degree of coiling of glands.

All measurements (in $\mu \mathrm{m}$ ) were made at four separate locations using an eyepiece micrometer. The number of gland coils was estimated by counting the number in contact with an arbitrary line extending perpendicularly from the myometrium to the luminal epithelium.

Histological data were subjected to standard analyses of variance.

\section{RESULTS}

Ewes in oestrus

Fifteen of nineteen spayed ewes and all of the entire animals were in oestrus at the time of insemination.

\section{Numbers of spermatozoa recovered}

Table 1 presents the main effects and Table 2 the significant interactions.

Spayed ewes had significantly fewer spermatozoa than entire ewes in all divisions of the tract $(P<0.05$ to $P<0.001)$. Significantly fewer spermatozoa were in the vagina and cervix at $24 \mathrm{hr}$ than at $2 \mathrm{hr}(P<0.001)$, while significantly more were in the Fallopian tubes. Natural mating was associated with larger mean numbers of spermatozoa recovered from the cervix than were recovered following artificial insemination $(P<0.05)$. This was due primarily to the higher numbers present $24 \mathrm{hr}$ after insemination (type of mating $\times$ time of recovery interaction; $P<0.01$; Table $2 \mathrm{~A}$ ).

Numbers of spermatozoa recovered from the Fallopian tubes were also increased following normal mating $(P<0.001)$ although mean numbers recovered from the uterus were apparently unaffected.

Overall, there was a gradient of mean numbers of spermatozoa in the cervix, with most in the caudal and least in the cranial sections $(P<0.01)$. However, numbers recovered from the cranial cervix were similar at both times of recovery, whereas populations of spermatozoa within the mid and caudal sections dropped sharply between 2 and $24 \mathrm{hr}(P<0.001$; Tables $2 \mathrm{~B}$ and 3$)$. The distribution of spermatozoa within the cervix also differed greatly between spayed and entire ewes. In the former, a much lower proportion of the population recovered $2 \mathrm{hr}$ after insemination was in the cranial and mid thirds of 
the cervix and very few spermatozoa were maintained in any section $24 \mathrm{hr}$ after insemination $(P<0.01$; Tables $2 \mathrm{C}$ and 3$)$.

Histology

A summary of the histological observations is presented in Table 4. The height of the luminal epithelium of spayed ewes was less than that in the entire

TABle 2

ESTIMATED NUMBERS OF SPERMATOZOA RECOVERED FROM THE CERVIX OF SPAYED AND ENTIRE EWES AT DIFFERENT TIMES AFTER MATING AND ARTIFIGIAL INSEMINATION

\begin{tabular}{|c|c|c|c|c|}
\hline \multicolumn{5}{|c|}{ Significant interactions } \\
\hline \multicolumn{5}{|c|}{$\begin{array}{l}\text { A. Type of mating } \times \text { time of recovery } \\
\mathbf{F}=7.57 ; \text { d.f. }=1 ; P<0.01\end{array}$} \\
\hline \multirow{2}{*}{$\begin{array}{l}\text { Time of } \\
\text { recovery }\end{array}$} & \multicolumn{4}{|c|}{ Type of mating } \\
\hline & \multicolumn{2}{|c|}{ Artificial insemination } & \multicolumn{2}{|c|}{ Natural mating } \\
\hline $\begin{array}{r}2 \mathrm{hr} \\
24 \mathrm{hr}\end{array}$ & \multicolumn{2}{|c|}{$\begin{array}{r}34019(7.242) \\
3150(5.450)\end{array}$} & \multicolumn{2}{|c|}{$\begin{array}{r}27524(7 \cdot 252) \\
5383(6 \cdot 371)\end{array}$} \\
\hline \multicolumn{5}{|c|}{$\begin{array}{l}\text { B. Position of cervix } \times \text { time of recovery } \\
\mathrm{F}=19.59 ; \text { d.f. }=2 ; P<0.001\end{array}$} \\
\hline \multirow{2}{*}{$\begin{array}{l}\text { Time of } \\
\text { recovery }\end{array}$} & \multicolumn{4}{|c|}{ Cervical region } \\
\hline & Caudal & & & Cranial \\
\hline $\begin{array}{r}2 \mathrm{hr} \\
24 \mathrm{hr}\end{array}$ & $\begin{array}{r}20211(7 \cdot 114) \\
717(5 \cdot 251)\end{array}$ & & & $\begin{array}{l}1176(5 \cdot 369) \\
1641(5 \cdot 216)\end{array}$ \\
\hline
\end{tabular}

C. Type of ewe $\times$ position of cervix $\mathrm{F}=6.23 ;$ d.f. $=2 ; P<0.01$

\begin{tabular}{c|c|c|c}
\hline \multirow{2}{*}{$\begin{array}{c}\text { Type of } \\
\text { ewe }\end{array}$} & \multicolumn{3}{|c}{ Cervical region } \\
\cline { 2 - 4 } & Caudal & Mid & \multicolumn{1}{c}{ Cranial } \\
\hline $\begin{array}{c}\text { Spayed } \\
\text { Entire }\end{array}$ & $\begin{array}{r}6080(5 \cdot 719) \\
15148(6 \cdot 613)\end{array}$ & $\begin{array}{r}1896(4 \cdot 756) \\
9698(6 \cdot 590)\end{array}$ & $\begin{array}{r}150(4 \cdot 462) \\
2670(6.084)\end{array}$ \\
\hline
\end{tabular}

Values expressed as mean numbers of spermatozoa $\times 10^{3}$ $\left(\log _{10}(x+2)\right.$ in parentheses)

animals but differences were more evident in the subepithelial stroma (Pl. 1, Figs 1 to 4). Within the stroma, oedema was markedly reduced and the nuclei appeared more compact. This also was the case in the stroma of the glandular region in the spayed animals.

Glandular proliferation was not so far advanced in spayed as in entire ewes, shown by the lower epithelial cell heights and a smaller number of gland coils $(P<0.01$ to $P<0.001)$. There was also a marked diminution in cytoplasm, apparent crowding together of nuclei, and an almost complete absence of 


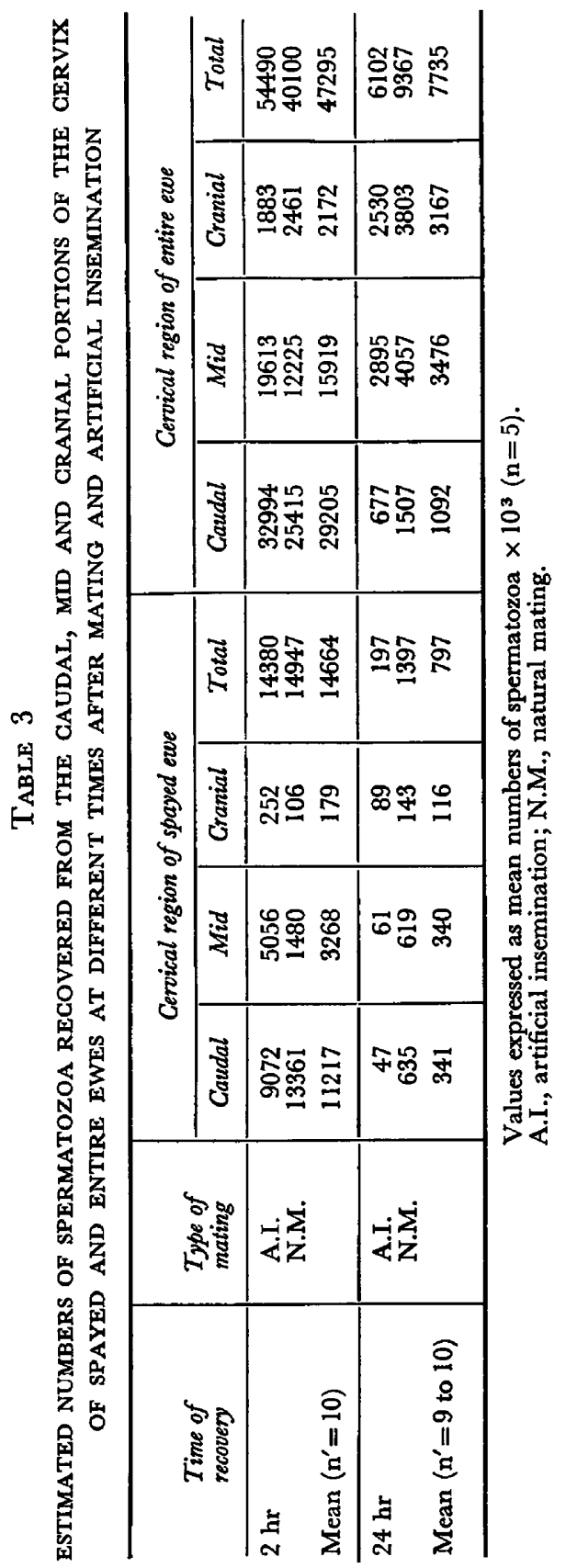


mitotic figures (Pl. 1, Figs. 5 to 8) which were frequent in samples from entire ewes (Pl. 1, Fig. 9). There were no apparent differences between spayed and entire ewes in the amount of PAS-positive material.

The widths of the myometrium and of the longitudinal muscles were reduced in spayed ewes but no other histological differences were apparent within this region.

TABLE 4

HISTOLOGICAL MEASUREMENTS ON THE UTERI OF SPAYED AND ENTIRE EWES AT DIFFERENT TIMES AFTER SAMPLING

\begin{tabular}{|c|c|c|c|c|c|}
\hline \multirow[b]{2}{*}{ Main effects } & \multicolumn{5}{|c|}{ Histological parameter measured } \\
\hline & $\begin{array}{c}\text { Height of } \\
\text { luminal } \\
\text { epithelial } \\
\text { cells }(\mu m)\end{array}$ & $\begin{array}{l}\text { Height of } \\
\text { glandular } \\
\text { epithelial } \\
\text { cells }(\mu \mathrm{m})\end{array}$ & $\begin{array}{l}\text { Width of } \\
\text { myometrium } \\
(\mu m)\end{array}$ & $\begin{array}{c}\text { Width of } \\
\text { longitudinal } \\
\text { muscle } \\
(\mu \mathrm{m})\end{array}$ & $\begin{array}{l}\text { No. of } \\
\text { gland } \\
\text { coils* }\end{array}$ \\
\hline $\begin{array}{l}\text { Type of ewe (N=19 to } 20) \\
\text { Spayed } \\
\text { Entire }\end{array}$ & $\begin{array}{l}28 \cdot 8 \dagger \\
24 \cdot 4\end{array}$ & $\begin{array}{l}20 \cdot 0 \\
13.9\end{array}$ & $\begin{array}{l}2071 \\
1627\end{array}$ & $\begin{array}{l}419 \\
307\end{array}$ & $\begin{array}{l}8 \cdot 7 \\
6 \cdot 8\end{array}$ \\
\hline$P$ & N.S. & $<0.001$ & $<0.001$ & $<0.05$ & $<0.01$ \\
\hline $\begin{array}{l}\text { Time of sampling (N=19 to } 20) \\
2 \mathrm{hr} \\
24 \mathrm{hr}\end{array}$ & $\begin{array}{l}23 \cdot 6 \\
25 \cdot 2\end{array}$ & $\begin{array}{l}13 \cdot 6 \\
14 \cdot 2\end{array}$ & $\begin{array}{l}1585 \\
1667\end{array}$ & $\begin{array}{l}296 \\
318\end{array}$ & $\begin{array}{l}7 \cdot 0 \\
6 \cdot 6\end{array}$ \\
\hline$P$ & N.S. & $<0.05$ & $<0.001$ & N.S. & N.S. \\
\hline
\end{tabular}

N.S., not significant.

* Number of glands in contact with an arbitrary line from the myometrium to the luminal epithelium.

$\dagger$ Values expressed as mean measurement at four locations within each sample.

\section{DISCUSSION}

Spayed ewes had fewer spermatozoa than entire ewes in all sections of the tract for all treatment combinations. Numbers of spermatozoa in the cervix in spayed ewes were similar to those reported by Mattner (1963) and Mattner \& Braden $(1963,1967)$ for spayed and entire ewes, respectively. These numbers, however, represented only some $30 \%$ and $10 \%$ of the numbers recovered from entire ewes 2 and $24 \mathrm{hr}$, respectively, after insemination. Flushing techniques used by Mattner \& Braden (1963) for the recovery of cervical spermatozoa result in approximately $50 \%$ of the total numbers being recovered (Mattner, 1968). A much higher rate of recovery than $50 \%$ is obtained as a result of the method of recovery employed in this experiment, which partially accounts for the high numbers of cervical spermatozoa recovered in entire ewes.

Although spermatozoa entered the caudal cervix of the spayed ewes in large numbers, relatively few were found in the mid and cranial thirds and subsequently in the uterus and Fallopian tubes. Reduced numbers in the uterus and Fallopian tubes are almost certainly a reflection of low numbers in the cervix and, in particular, in the cranial third.

Evidence of an increase in numbers of spermatozoa in the uterus and Fallopian tubes from 2 to $24 \mathrm{hr}$ after insemination is in agreement with that in 
earlier reports (Mattner, 1963; Quinlivan \& Robinson, 1967, 1969). The observation that natural mating had no appreciable effect on vaginal numbers of spermatozoa even $2 \mathrm{hr}$ after insemination was unexpected. Ewes artificially inseminated received about $300 \times 10^{6}$ spermatozoa, while animals naturally mated twice would be expected to have had an initial vaginal pool far in excess of this number. Obviously, a high proportion of the inseminate was lost within $2 \mathrm{hr}$ of mating.

Despite the lack of a demonstrable difference at $2 \mathrm{hr}$ in numbers of spermatozoa in the vagina and cervix of naturally mated as compared with artificially inseminated ewes, natural mating resulted in higher cervical populations at $24 \mathrm{hr}$ in both spayed and entire ewes. There is no obvious explanation for this finding.

Comparative failure of sperm transport in spayed ewes is probably due to a combination of factors - cervical secretions, motility of the reproductive tract and phagocytosis of spermatozoa within the tract. The quantitative production of cervical mucus during oestrus is comparable for entire ewes and spayed ewes treated with $25 \mu \mathrm{g}$ ODB (Allison, 1972). Consequently, it is not easy to implicate differences in production of cervical mucus in the relatively inefficient sperm transport in spayed ewes. Subtle differences in qualitative characteristics of the mucus, however, may be involved.

The rôle of uterine motility in the transport of spermatozoa in the ewe is uncertain (Lightfoot \& Restall, 1971). The pattern of contractility is modified at oestrus (Lightfoot, 1969) and can be altered by treatment with oestrogen (Brinsfield, 1968). There is a distinct possibility that the uterine motility of the progesterone-oestrogen-treated spayed ewe differed from that of the normal oestrus ewe, so affecting the pattern of sperm transport.

The phagocytic response to spermatozoa within the uterus of spayed ewes had been studied in entire animals by Brinsfield, Hawk \& Righter (1964) and by Mattner (1969). It is possible that an inadequate endocrine regimen in the spayed ewes may have contributed to the inefficient maintenance of the cervical population, particularly in the cranial and mid sections, due to leucocytic invasion from the uterus (Mattner, 1968).

The nature of the structural involution of the reproductive tract in the absence of the ovaries has been reviewed by Parkes \& Deanesly (1966) who state that, in general, administration of oestrogens to the spayed animal will produce most, if not all, of the extra-ovarian histological and physiological changes

\section{EXPLANATION OF PLATE 1}

Histology of the uterine endometrium from entire and spayed ewes. $\times 280$.

FIGs I and 2. Luminal epithelium and subepithelial stroma from entire ewes at oestrus. Figs 3 and 4. Luminal epithelium and subepithelial stroma from spayed ewes in which oestrus was induced. Compared with entire animals, stromal oedema is markedly reduced in spayed ewes and there is a marked compaction of nuclei.

Figs 5 and 6 . Mid-gland region. Samples from entire ewes at oestrus.

FIGs 7 and 8. Mid-gland region from spayed ewes in which oestrus was induced. In these samples, there is a reduction in glandular epithelial cell height, crowding together and compaction of nuclei, and an apparent loss of cytoplasm.

Frg. 9. Mitotic figures (arrowed) in the upper gland region in a sample from an entire ewe at oestrus. 

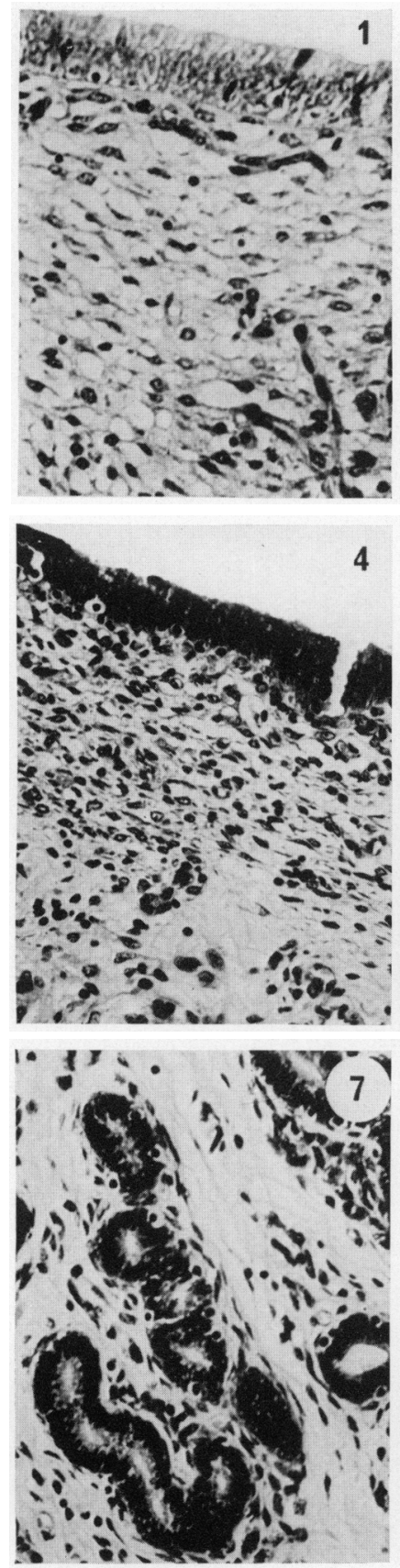
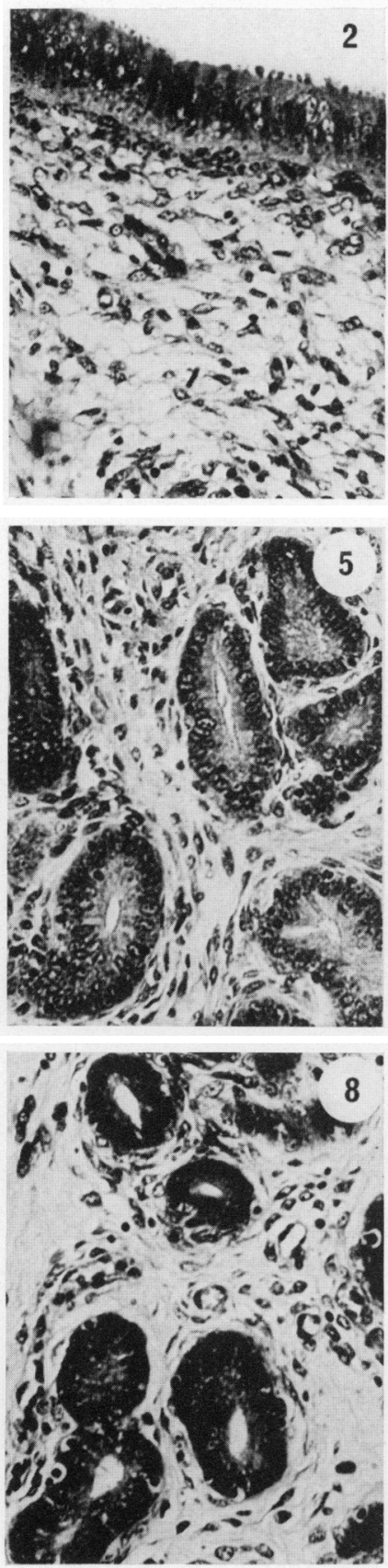
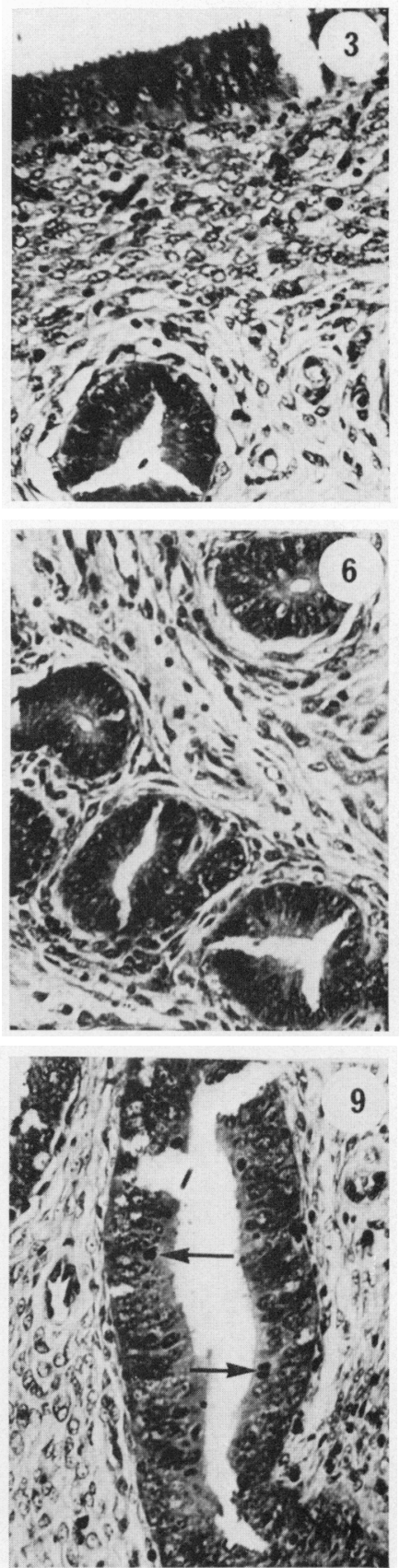
associated with the normal oestrous cycle. Examination of Table 4 and Plate 1 indicates that the uterus of the spayed ewe treated with $10 \mathrm{mg}$ progesterone/ day followed by $25 \mu \mathrm{g}$ ODB is not maintained in a normal physiological state when compared with that of the entire animal. The reduction in all histological parameters measured may have been due to inadequate oestrogen. It appears that the uteri of the spayed ewes were undergoing an early stage of atrophy, although all had been injected with ovarian steroids from the day of ovariectomy. Thus, hormonal regimens which will result in behavioural oestrus of normal duration (Fletcher, 1968) will not maintain the functional integrity of the uterus.

\section{AGKNOWLEDGMENTS}

Grateful acknowledgment is made to Professor T. J. Robinson for encouragement and valuable criticism of the manuscript, and to Mr R. G. Sinclair, Mrs C. E. Gamage and Mrs R. I. Hartmann for technical assistance. Financial support was provided by G. D. Searle (Aust.) Ltd and the Australian Research Grants Committee. The author was the recipient of an Australian Commonwealth Scholarship.

\section{REFERENCES}

Allison, A. J. (1972) Production of cervical mucus in ewes treated with exogenous progestagen and oestrogen. Aust. J. agric. Res. 23, 473.

Allison, A. J. \& Robrnson, T. J. (1972) The recovery of spermatozoa from the reproductive tract of the spayed ewe treated with progesterone and oestrogen. F. Reprod. Fert. 31, 309.

Brinsfield, T. H. (1968) Relationship of endocrine state to spontaneous motility in sheep myometrium in vitro. 7. Anim. Sci. 27, 439.

Brinsfield, T. H., HAWK, H. W. \& Righter, H. F. (1964) Interaction of progesterone and oestradiol on induced leucocytic emigration in the sheep uterus. F. Reprod. Fert. 8, 293.

Cochran, W. G. \& Cox, G. M. (1957) Experimental designs, 2nd edn. John Wiley, New York.

FLETCHER, I. G. (1968) Interrelationships between hormones, behaviour and fertility in the ewe. Ph.D. thesis, University of Sydney.

Lightroot, R. J. (1969) The deep-frozen preservation, physiological transport and fertility of ram spermatozoa. Ph.D. thesis, University of Sydney.

Lightfoot, R. J. \& Restall, B. J. (1971) Effects of site of insemination, sperm motility and genital tract contractions on the transport of spermatozoa in the ewe. 7. Reprod. Fert. 26, 1.

Mattner, P. E. (1963) Spermatozoa in the genital tract of the ewe. II. Distribution after coitus. Aust. 7. biol. Sci. 16, 688 .

MATTNER, P. E. (1968) The distribution of spermatozoa and leucocytes in the female genital tract in goats and cattle. F. Reprod. Fert. 17, 253.

Mattner, P. E. (1969) Differential leucocytic response to spermatozoa in the cervix and the uterus in ewes. F. Reprod. Fert. 18, 297.

Mattner, P. E. \& Braden, A. W. H. (1963) Spermatozoa in the genital tract of the ewe. 1. Rapidity of transport. Aust. F. biol. Sci. 16, 473.

Mattner, P. E. \& Braden, A. W. H. (1967) Studies in flock mating of sheep. 2. Fertilisation and prenatal mortality. Aust. 7. exp. Agric. Anim. Husb. 7, 110.

Parkes, A. S. \& Deanesly, R. (1966) The ovarian hormones. In: Marshall's Physiology of Reproduction, Vol. III, p. 570. Ed. A. S. Parkes, Longmans, Green. London.

Quinlivan, T. D. \& RoBinson, T. J. (1967) The number of spermatozoa in the Fallopian tubes of ewes at intervals after artificial insemination following withdrawal of SC- 9880 impregnated intravaginal sponges. In: The Control of the Ovarian Cycle in the Sheep, p. 117. Ed. T. J. Robinson, Sydney University Press.

Quintrvan, T. D. \& Robinson, T. J. (1969) Numbers of spermatozoa in the genital tract after artificial insemination of progestagen-treated ewes. F. Reprod. Fert. 19, 73. 